\title{
YMPÄRISTÖÄ SÄÄSTÄVÄMPIÄ TEKSTIILEJÄ SAIRAALOIHIN
}

Opas ympäristöä säästäviin

hankintoihin terveydenhuoltosektorilla

$\mathbb{1}$ Pohjoismaiden ministerineuvosto 
YMPÄRISTÖÄ SÄÄSTÄVÄMPIÄ TEKSTIILEJÄ SAIRAALOIHIN

Opas ympäristöä säästäviin hankintoihin terveydenhuoltosektorilla

David Watson, Rikke Fischer-Bogason

ISBN 978-92-893-5061-7 (PRINT)

ISBN 978-92-893-5062-4 (PDF)

ISBN 978-92-893-5063-1 (EPUB)

http://dx.doi.org/10.6027/ANP2017-741

ANP 2017:741

@ Pohjoismaiden ministerineuvosto 2017

Ulkoasu: Gitte Wejnold

Kansikuva: Pexels.com

Kuvat: Scanpix.dk

www.norden.org/nordpub

Pohjoismaisia julkaisuja voi ladata

osoitteesta www.norden.org/nordpub

\section{Pohjoismainen yhteistyö}

Pohjoismainen yhteistyö on yksi maailman laajimmista alveellisista

yhteistyömuodoista. Yhteistyön piiriin kuuluvat Islanti, Norja, Ruotsi, Suomi ja

Tanska sekä Ahvenanmaa, Färsaaret ja Grönlanti.

Pohjoismaista yhteistyötä tehdään politiikan, talouden ja kulttuurin aloilla tärkeänä osana eurooppalaista ja kansainvälistä yhteistyötä. Pohjoismaisen yhteisön tavoitteena on vahva Pohjola vahvassa Euroopassa.

Pohjoismainen yhteistyö pyrkii vahvistamaan pohjoismaisia ja alveellisia etuja ja arvoja globaalissa maailmassa. Maiden yhteiset arvot lujittavat osaltaan Pohjolan asemaa yhtenä maailman innovatiivisimmista ja kilpailukykyisimmistä alueista.

Pohjoismaiden ministerineuvosto

Ved Stranden 18

1061 København K

www.norden.org 


\section{YMPÄRISTÖÄ SÄÄSTÄVÄMPIÄ TEKSTIILEJÄ SAIRAALOIHIN}

Opas ympäristöä säästäviin

hankintoihin terveydenhuoltosektorilla 


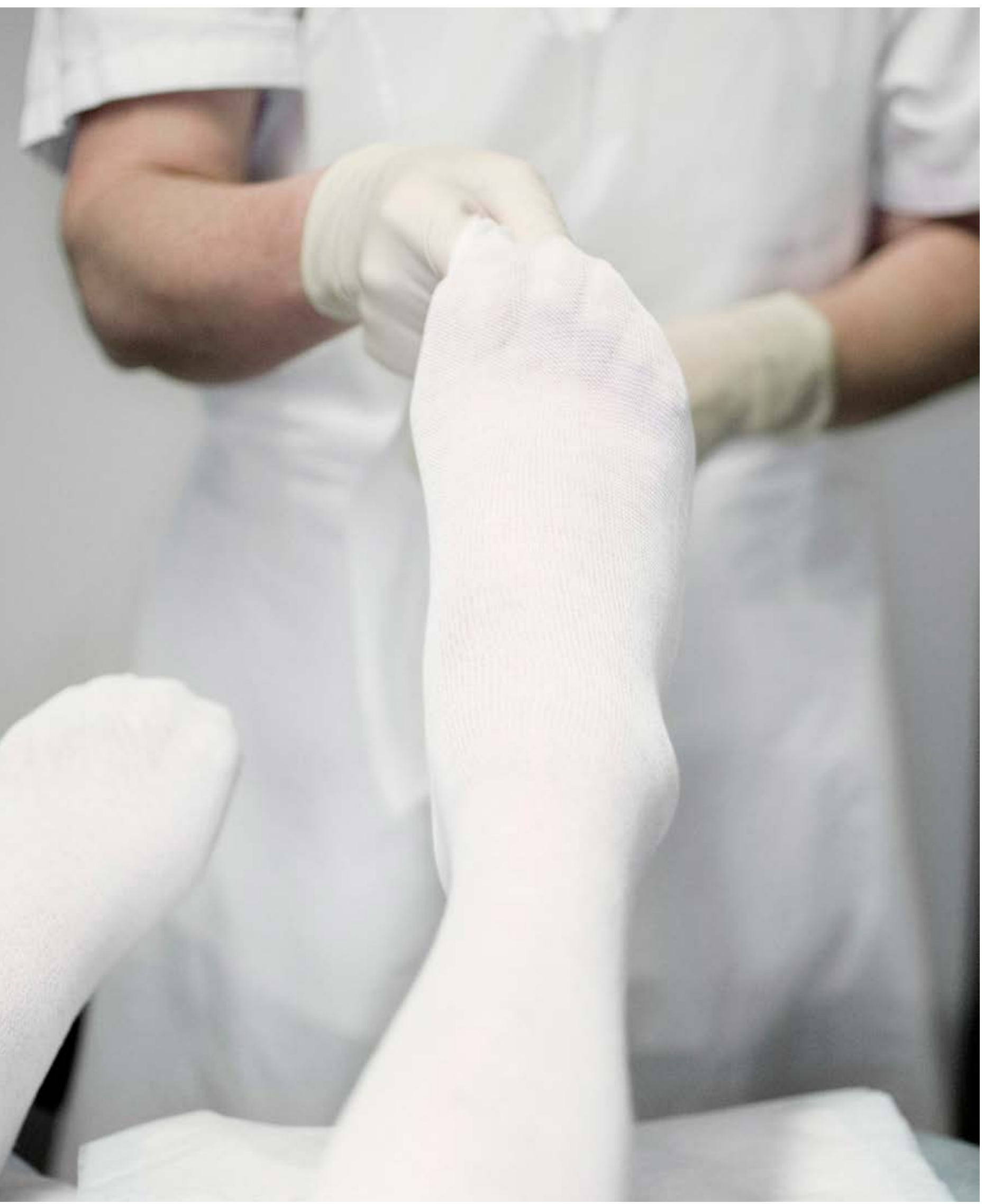




\section{SISÄLLYS}

6 Miten tätä opasta käytetään

8 Luku 1

Tärkeimmät muistettavat asiat

10 Luku 2

Hankintaprosessi, neuvottelumenettely ja innovaatio

15 Luku 3

Linkkejä hyödyllisiin asiakirjoihin ja resursseihin

22 Luku 4

Pikakatsaus ympäristömerkkeihin

24 Luku 5

Kuidun valinta

28 Luku 6

Kertakäyttöiset vs. monikäyttöiset tekstiilit

30 Luku 7

Kokonaiskäyttökustannusten käyttö

33 Luku 8

Tietoja oppaasta ja sen taustaverkostostosta 


\section{Miten tätä opasta käytetään}

Tämä opas on kohdistettu sairaalasektorin hankintayksiköille, jotka suunnittelevat tarjouskilpailua tekstiilituotteille ja palveluille. Opas auttaa laatimaan kohtuulliset ja mahdolliset ympäristökriteerit ja tarjoaa taustatietoja tärkeimmistä huomioitavista asioista pyrittäessä vähentämään tekstiilien käytön ympäristövaikutuksia.

Opasasiakirjoista voi olla paljon apua hankintojen tekemisessä, ja ne inspiroivat toteuttamaan ympäristöllisiä ja yhteiskunnallisia parannuksia julkisten hankintojen kautta. Tästä oppaasta saat tietoja tekstiilihankintojen ympäristövaikutuksista, saatavilla olevista ympäristömerkeistä ja valmiista kriteereistä, ja mitä tekstiilin käyttöiän tekijöitä on tärkeää huomioida. On kuitenkin tärkeää, että jokaista hankintaprosessia ajatellaan tietyn organisaation ja tuotteen kontekstissa, ja että hankintayksikkö huomioi kriteerien määrittelyn vaikutukset organisaatioon sekä käyttäjään.

Hygienian huomioiminen on aina tärkeintä terveyssektorin tekstiileihin liittyvissä päätöksissä. Käyttömukavuudesta ei saa myöskään tinkiä. Molemmat näistä voidaan ottaa huomioon ja samalla vähentää ympäristövaikutuksia. 


\section{HANKINTOJEN MONIMUTKAINEN MAISEMA}

Pohjoismaisella terveydenhuollon sektorilla on käytössään useita malleja tekstiilien hankinnasta. Eroja on hankinnan järjestelyissä ja siinä, mitä hankitaan.

\section{- Miten hankinnat järjestetään?}

Tämä on monimutkaista ja vaihtelee maittain ja joissakin tapauksissa alveittain. Tanskassa alveet laativat hankintakehyksen, jota yksittäiset sairaalat käyttävät päivittäisiä tilauksia tehdessään. Norjassa keskitetty hankintaorganisaatio perustaa hankintakehyksiä, joita yksittäiset sairaalasäätiöt voivat hyödyntää, tai muutoin ne järjestävät omat hankintansa. Ruotsissa rakenne on muodoltaan "ad hoc" ja alveet/maakäräjät tekevät joissakin tapauksissa yhteistyötä kehyshankintasopimuksien teossa samalla, kun yksittäiset sairaalat tekevät pienempiä tilauksia. Yleisesti kehyssopimukset vähentävät byrokratiaa ja tarjouspyyntöjen laatimiseen tarvittavia resursseja, ja niillä voidaan varmistaa halvemmat hinnat suurempien tilausmäärien ansiosta.

\section{- Mitä hankitaan?}

Tyypillinen kehyssopimus sisältää kymmenittäin, ellei sadoittain tekstiilituotteita petivaatteista potilaiden vaatteisiin, henkilöstön työasuihin ja leikkaussalin tekstiileihin. Alveet ja sairaalasäätiöt voivat ostaa lisäksi tai vaihtoehtoisesti tekstiili- tai pesulapalveluita. Erityisesti pesulapalveluita hankkivat usein yksittäiset sairaalat tai sairaalaryhmät, jotka tekevät yhteistyötä pesulan kanssa, sen sijaan että ne tehtäisiin alve- tai valtiotason hankintoina. Pesulat voivat olla yksityisessä omistuksessa, sairaalasäätiön omistamia, mutta omalla budjetillaan toimivia tai julkisomisteisia, jolloin sairaaloilla ja paikallishallinnolla on yhteinen omistajuus. 
Luku 1

\title{
Tärkeimmät muistettavat asiat
}

\author{
Tekstiilien kulutus on vastuussa 4-6 \% eurooppalaisen kulutuksen \\ kokonaisympäristövaikutuksista'. Nämä vaikutukset aiheutuvat sekä tekstiilien \\ tuotannosta että niiden käytön aikaisesta huollosta. Monikäyttöisten \\ terveydenhuollon tekstiilien ympäristövaikutukset painottuvat enemmän \\ käyttövaiheeseen, kun taas kertakäyttöisten tuotteiden vaikutukset painottuvat \\ tuotantovaiheeseen.
}

Tämä opas keskittyy ympäristöä säästäviin hankintoihin, eli miten terveydenhuollon hankintayksiköt voivat vähentää hankintojensa ympäristövaikutuksia. Hankintayksiköt voivat olla kuitenkin lisäksi kiinnostuneita pyrkimään kestäviin hankintoihin, joihin kuuluvat myös tuotteiden toimittamiseen liittyvät eettiset näkökulmat. Sivulla 18 olevassa laatikossa luetellaan resursseja, jotka ovat apuna eettisten kriteerien muodostamisessa.

Ympäristövaikutusten vähentämiseksi kannattaa keskittyä molempiin alueisiin: ostamiesi/vuokraamiesi tekstiilien valintaan ja siihen miten ne pestään (vaikka et ehkä pysty vaikuttamaan jälkimmäiseen). On myös tärkeää tiedostaa näiden väliset yhteydet. Eri kuitutyypit voivat vaatia erilaisia käsittelytapoja.

Voit harkita molempia näistä asioita riippumatta siitä ostatko ja omistatko tekstiilit ja ostat pesulapalvelut; vai vuokraatko tekstiilipalvelut pakettina.

Tuotantoon perustuvat vaikutukset: Monet tuotantovaikutukset johtuvat valmistuksessa käytetyistä kemikaaleista ja energiasta. Lisäksi monien tuotannon aikana käytettyjen haitallisten kemikaalien jäämiä voivat jäädä tekstiilituotteisiin ja aiheuttaa terveydellisen riskin herkille käyttäjille.

Nämä asiat otetaan hyvin huomioon eri ympäristömerkeissä, erityisesti Joutsenmerkityissä ja
EU-ympäristömerkityissä tuotteissa (ks. luku 4, sivu 22) sekä EU:n tekstiilejä koskevissa GPP-kriteereissä. Ne on huomioitu myös monissa kansallisissa GPP-oppaissa (ks. luku 3, sivu 19).

Kuitutyypin valinta on myös tärkeä: puuvillan tuotannolla on suuria vaikutuksia, jotka aiheutuvat erityisesti torjunta-aineiden, maan ja veden runsaasta käytöstä. Luonnonmukainen valinta vähentää joitakin näistä vaikutuksista, mutta samoin voi tehdä myös vaihto muihin kuituihin, kuten polyesteriin. Tästä on enemmän luvussa 5, sivuilla $24-25$.

Yksi erittäin tärkeä, mutta usein huomiotta jätetty tapa vähentää tuotannon kaikkia ympäristövaikutuksia, on pidentää käyttöikää mahdollisimman pitkäksi. Näin säästyy myös rahaa (katso luku 7, sivut 30 - 31). Hankintayksikkönä voit auttaa 1) valitsemalla kestävän kuidun (ks. luku 5, sivut $24-25$ ), 2) valitsemalla värejä, jotka kestävät pesua parhaiten sekä potilaiden että henkilöstön käytössä ja 3) laatimalla pesulapalveluille kriteerit, joilla vähennetään tekstiilien kulumista. Joihinkin ympäristömerkkeihin (ks. luku 4) liittyy kestävyyskriteereitä, kuten myös eurooppalaisiin (EN) ja kansallisiin tekstiilistandardeihin ${ }^{2}$, mutta ne ovat luonteeltaan hyvin perustasoisia. Asiakirjat tekstiilien käyttö- ja pesukerroista kannattaa hankkia toimittajilta.

\footnotetext{
1 EEA (2014) Environmental Indicator Report 2014 http://www.eea.europa.eu/publications/environmental-indicator-report-2014

${ }^{2}$ Katso esimerkki kansainvälisistä ja norjalaisista standardeista norjalaisen standardin listaamana https://www.standard.no/no/ Nettbutikk/produktkatalogen/?ProdCat $=11360430$
} 


\section{SAIRAALOIDEN LOGOT JA TARPEETTOMAN JÄTTEEN VÄLTTÄMINEN}

On kaksi tilannetta, jolloin voidaan joutua hävittämään suuria määriä toimivia terveydenhuollon tekstiilejä: 1) tekstiilejä vuokraavan palveluntarjoajan vaihto ja 2)

sairaalan, sairaanhoitopiirin tai alueen logon uudelleenbrändäys/vaihto.

Tämän merkittävän resurssien hukkaamisen välttämiseksi on useita vaihtoehtoisia tapoja:

Kirjaa tekstiilipalveluyrityksen sopimukseen, että sairaala voi ostaa tekstiilit sopimuskauden lopussa.

1. Valitse tekstiileihin neutraalit merkinnät, jotta niitä voidaan vaihdella sairaanhoitopiirien, sairaaloiden ym. välillä.

2. Kysy toimittajalta, voidaanko tekstiilit merkitä poistettavilla logoilla

Käyttövaiheen vaikutukset: Hygienia on tietenkin tärkein asia tekstiilien pesussa. Pesun vaikutuksia voidaan kuitenkin vähentää tekemättä kompromisseja hygienian suhteen. Tällaisia keinoja ovat parempi vesi- ja energiatehokkuus, ympäristöystävällisempien pesuaineiden käyttö ja ekotehokas logistiikka. Joissakin maissa (esim. Tanskassa ja Norjassa) sairaalan pesulan hygieniaohjeissa sallitaan alemmat pesulämpötilat, jos käytetyillä pesuaineilla on sama steriloiva vaikutus (ks. sivut $16-17$ ).

Tekstiilipalveluiden Joutsenmerkki tarjoaa kattavan yhteenvedon mahdollisista parannuksista. Huomaa, että vaikka pesulapalvelulla onkin Joutsenmerkki, se voi koskea vain tärkeimpiä ympäristövaikutuksia vähentäviä tekijöitä (ks. lisätietoja asiasta luvusta 4, sivu 22).
Vaikkei kuidun valinta liitykään Joutsenmerkkiin, se voi vaikuttaa pesun ympäristövaikutuksiin (ks. luku 5, sivu 24).

Poistovalinnat ovat usein ongelma ympäristöpäätöksissä. Varmistamalla, että tekstiilihuoltopalvelujen tarjoaja kierrättää poistotekstiilinsä saavutetaan tiettyjä etuja, mutta käyttövaiheen pidentäminen on kokonaisympäristövaikutuksen kannalta merkittävämpää.

Yleiskuva ympäristövaikutuksista löytyy ruotsalaisen kansallisen julkisten hankintojen laitoksen tausta-asiakirjasta koskien tekstiilejä, laitoksen tausta-asiakirjasta koskien tekstiilipalveluita ja EU:n yhdistetyn tutkimuksen keskuksen elinkaarianalyysiraportista. 
Luku 2

\title{
Hankintaprosessi, neuvottelumenettely ja innovaatio
}

\author{
Hankintaprosessi voi olla monimutkainen ja siihen voi liittyä useita vaiheita ja \\ strategisia päätöksiä. Ympäristökriteerien sisällyttäminen tarjouspyyntöön tulee \\ päättää valmisteluvaiheessa, jotta voidaan varmistaa oikeiden kysymyksien \\ kysyminen ja päätöksenteon oikea-aikaisuus.
}

Ensiksi on päätettävä hankitaanko tuotteita vai toimintoja. Kun tuoteryhmänä on tekstiilit, se tarkoittaa, että on olennaista miettiä, ostetaanko tekstiilit vai ostetaanko pääsy tekstiileihin - eli vuokrataanko ne.

Tekstiilien vuokraamisella voi olla positiivinen ympäristövaikutus. Tämä johtuu siitä, että tuotteen omistus säilyy toimittajalla, jolla on taloudellinen intressi varmistaa tuotteensa pitkä käyttöikä. Mitä pidempään tuotetta käytetään, sitä pienempi on sen ympäristövaikutus ja sitä vähemmän se käyttää luonnonresursseja.

Huolimatta siitä, päätetäänkö tekstiilejä ja tekstiilipalveluita ostaa vai vuokrata, on tärkeää konsultoida markkinoita alustavassa markkinoiden vuoropuhelussa. Neuvottelumenettelyn kautta saadaan tietoa saatavilla olevista tuotteista, niiden ympäristöominaisuuksista ja muista olennaisista laatuun liittyvistä tekijöistä (ks. esimerkki sivulla 11).

Neuvottelumenettely on vuoropuhelua asiakkaan ja mahdollisten toimittajien välillä. Se suoritetaan ennen virallista tarjouskilpailua, jotta voidaan varmistaa, että kilpailutus on realistinen ja heijastaa sitä, mitä markkinoilla on saatavilla, mutta on samalla myös kunnianhimoinen.
Neuvottelut voidaan viedä läpi monilla eri tavoilla, mutta on tärkeä muistaa, että neuvottelu on sallittu siihen asti, kun tarjouspyyntö on julkaistu. Julkaisun jälkeen neuvottelua potentiaalisten toimittajien kanssa rajoitetaan.

Mitä neuvottelumenettelyssä tulisi kysyä? Käsiteltäviä tekijöitä on monia, mutta ympäristöperspektiivistä katsoen tulisi keskustella seuraavista teemoista:

- Ympäristömerkittyjen tuotteiden saatavuus

- Orgaanisten puuvillapohjaisten tuotteiden saatavuus

- Vaihtoehtoisten kuitujen käyttö

- Tekstiilikuidun alkuperä

- Kierrätetty sisältö

- Kemikaalien, energian ja vedenhallinta tuotannossa

- Pesuun ja ylläpitoon liittyvät ominaisuudet

- Kestävyysominaisuudet, mukaan lukien korjattavuus

- Poistettavat logot

- Värin valinta ja ympäristövaikutukset

- Poistopotentiaali (voidaanko poistotekstiilejä kierrättää?)

Lisää pohdittavia inspiraatioteemoja ympäristökriteerien käytöstä löytyy EU-komission taustaasiakirjasta tekstiilien GPP-kriteereille. 


\section{NORJALAINEN SYKEHUSINNKJØP: ANNETAAN MARKKINOIDEN AUTTAA REALISTISTEN KRITEERIEN LAATIMISESSA}

Vuonna 2014 norjalainen Sykehusinnkjøp HF (aiemmin HINAS) hankki tekstiilejä terveydenhuoltosektorille. Se käytti markkinoiden vuoropuheluprosessia sopivien ympäristövaatimuksien asettamiseksi. Toimittajia rohkaistiin kommentoimaan kriteerien luonnoksia yksittäisissä vuoropuhelutapaamisissa. Toimittajia kutsuttiin julkisille hankinnoille tarkoitetun verkkotietokannan kautta.

Neuvottelumenettelyn vaikutuksesta hankintavaatimuksissa $100 \%$ puuvilla vaihdettiin kestävämpään polyesteri/puuvillaseokseen. Toimittajat neuvoivat hankkimaan Oeko-tex 100 -merkittyjä tekstiilejä, koska paljon useammat toimittajat pystyivät vuonna 2014 vastaamaan Oeko-tex 100 -merkin vaatimuksiin kuin esimerkiksi Joutsenmerkin tai EU-ympäristömerkin tiukempiin vaatimuksiin.

Sykehusinnkjøp HF antaa seuraavat ohjeet markkinoiden vuoropuheluun luontoa säästävämpien tekstiilien hankinnassa:

1. Hyödynnä markkinoiden kommentit kriteereitä laadittaessa ja varmista, että kriteerit ovat realistisia - eivätkä silti kunnianhimottomia.

2. Harkitse myös yksittäisiä tapaamisia varmistaaksesi, että toimittajat voivat puhua vapaasti ilman kilpailijoiden läsnäoloa.

3. Muista antaa toimittajien haastaa hankintatapasi - myös kuidun ja liiketoimintamallin suhteen. 
Ruotsin hankintaviranomainen (Upphandlingsmyndigheten) tarjoaa apua valtion organisaatioille markkinoiden vuoropuheluun liittymiseksi. Opastukseen kuuluvat tapaamiset ja työpajat laitoksessa. Katso lisätietoja tästä linkistä. Laitoksella on myös ohjelma, jolla se kehittää verkkoresursseja, jotka auttavat markkinoiden vuoropuhelussa. Verkossa oleva resurssipankki ei vielä sisällä terveydenhuollon tekstiilien resursseja.

Tekstiilien tuotannon uusien teknisten ratkaisujen nopeasta kehittymisestä johtuen on aina tärkeää liittyä markkinoiden vuoropuheluun: ympäristövaikutusten vähentäminen voivat olla mahdollisia tavoilla, joista sairaalan hankintayksiköt eivät ole tietoisia. Tuotantoprosesseihin ja -suunnitteluun on tulossa monia innvoaatioita, joista voi olla suuria ympäristöja hygieniaetuja (ks. sivu 13).

On huomattava, että innovatiiviset tekniikat voivat joskus aiheuttaa uusia ympäristöongelmia, mikä pitäisi selvittää ennen niiden käyttöönottoa.

Hankintayksiköt voivat myös varmistaa uusimpien innovaatioiden käyttämisen allekirjoittamalla kehityssopimuksen toimittajien kanssa. Se on pidempiaikainen sopimus, joka mahdollistaa toimittajan uusien tekniikoiden käytön sitä mukaa, kun niitä syntyy, jotta ympäristövaikutuksia voidaan vähentää edelleen. Kehityssopimus voi perustua toiminnallisille vaatimuksille (ks. alla oleva laatikko).

\section{TOIMINNALLISET VAATIMUKSET TARJOUSPYYNTÖASIAKIRJOISSA}

Jotta uusien, pienempien ympäristövaikutuksien tuotteiden kehittäminen olisi mahdollista, hankintasopimus voi perustua toiminnallisiin vaatimuksiin ennemmin kuin tietyn tuotteen määrittämiseen.

Tätä käytetään eniten esimerkiksi hankittaessa energia- tai valaistuspalveluita, mutta sitä voidaan myös käyttää terveydenhuollon tekstiileihin. Sopimuksessa voitaisiin esim. vaatia hoitohenkilöstön puhtaiden työasujen toimitusta, joka kattaa tietyn kokoaikaisen hoitohenkilöstömäärän tarpeen ja on hygienia-, kestävyys ja käyttömukavuusvaatimusten mukainen, mutta ilman vaatimusta tietystä kuitutyypistä. Palveluntarjoaja voi sitten valita kuidut, jotka ovat näiden standardien mukaisia, mutta myös parhaiten kestäviä, millä vähennetään kustannuksia ja ympäristövaikutuksia.

Ruotsin hankintalaitos on laatinut ohjeistuksen toiminnallisten vaatimusten laatimiseksi. Se löytyy tästä linkistä. 


\section{ESIMERKKEJÄ LUPAAVISTA INNOVAATIOISTA}

\section{Kuivavärjäys}

Monet innovatiiviset yritykset ovat kehittäneet kuivavärjäysprosesseja. Yhdessä esimerkissä käytetään hiilidioksidia veden sijaan, eikä lisätä kemikaaleja prosessiin värien liuottamiseksi. Lisäksi hiilidioksidi voidaan kerätä ja käyttää uudelleen. Kuivavärjäyksen avulla vältetään jätevesipäästöt, jotka voivat aiheuttaa tuotantolaitoksissa valtavia ympäristövaikutuksia. Se vähentää myös tekstiilien kuivatuksen tarvetta prosessien välillä, ja säästää näin energiaa.

\section{Biomimiikka}

Biomimiikka on luonnon oman suunnittelun käyttämistä ihmisen valmistamissa tuotteissa. Tällä alveella tehty tutkimus on jo johtanut sellaisten tekstiilien kehittämiseen, jotka jäljittelevät lootuksen lehdissä olevia tahrankestoominaisuuksia. Toiset luonnolliset käsittelyt ovat keskittyneet jäljittelemään ravun ja hummerin kuoren antimikrobisia ominaisuuksia. Näiden tekniikoiden tekstiilisovellukset ovat jo saaneet tuulta alleen, ja ne edistävät tekstiilien pesemistä alemmissa lämpötiloissa samalla, kun hygienian korkea taso säilytetään.

\section{Nanomateriaalit}

Nanomateriaalien integrointi tekstiilialustoihin voi lisätä tekstiilien kestävyyttä ja siten vähentää resurssien kulutusta ja kuluja. Nanomateriaaleilla voidaan saada aikaan tahrankestävyys, rypyttömyys, sähköisyyden poistuminen ja kuitujen sähkönjohtavuus ilman, että käyttömukavuudesta ja joustavuudesta täytyisi tinkiä. 


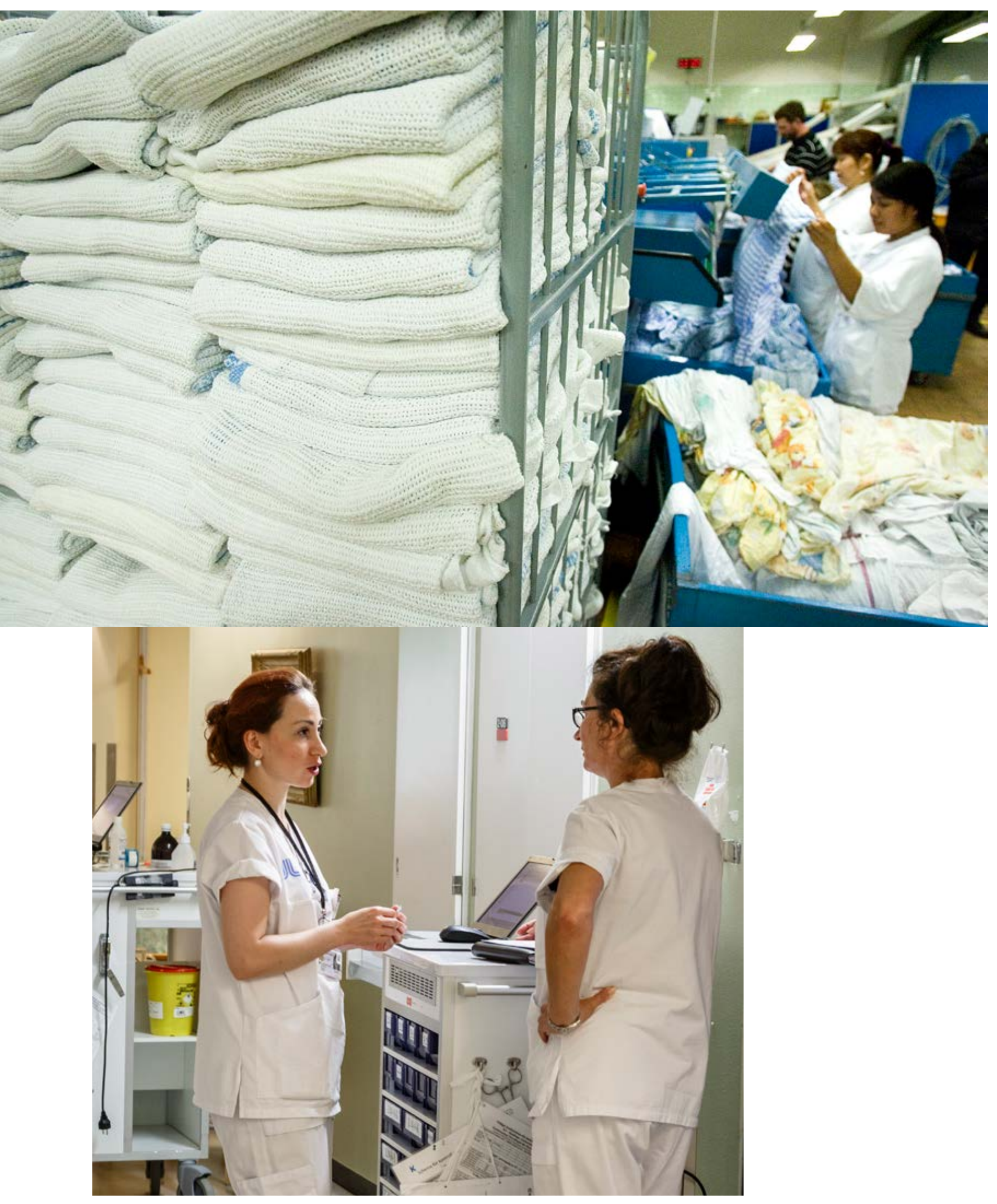


Luku 3

\title{
Linkkejä hyödyllisiin asiakirjoihin ja resursseihin
}

\author{
Saatavilla on useita oppaita, jotka auttavat hankkijoita huomioimaan tuotteiden \\ kestävyyden tekstiilejä ja tekstiilipalvelvita hankkiessaan. Mitkään näistä eivät koske \\ terveydenhuoltoalan tekstiilejä.
}

EU: EU on laatinut valinnaiset tekstiilejä koskevat ympäristöä säästävien

hankintojen kriteerit vuonna 2012 seuraavalla yleislogiikalla:

Tärkeimmät ympäristövaikutukset

Ympäristöä säästävien julkisten hankintojen

lähestymistapa

- Ilmansaasteet, otsonin muodostuminen (savusumu), bioakkumulaatio tai ruokaketjun altistuminen ja haitalliset vaikutukset vesieliöihin tai sellaisten ei-toivottujen vesiorganismien kasvun lisääntyminen, jotka voivat heikentää veden laatua, johtuen tiettyjen torjuntaaineiden ja lannoitteiden asiattomasta käytöstä kuitujen tuotannossa, ja aineista, joita on käytetty kuitujen ja lopullisten tekstiilituotteiden käsittelyn aikana.

- Haitallinen vaikutus käyttäjien työterveyteen johtuen tiettyjen ihmiselle haitallisten aineiden jäämistä.

- Aikaisen loppuun kulumisen ja siitä johtuvan tekstiilijätteen välttämiseksi käytetään värinkestäviä kankaita, jotka eivät kutistu käytössä.
- Hanki luonnonmukaisesti tuotettuja tekstiilejä.

- Hanki käytettyjä tekstiilejä, joita voidaan käyttää uudelleen niiden alkuperäiseen tarkoitukseen tai tekstiilejä, joissa on

$\longrightarrow$ kierrätettyjä kuituja.

- Hanki tekstiilejä, joiden tuotannossa on käytetty vähemmän ympäristölle haitallisia aineita.

- Hanki tekstiilejä, joissa on vähemmän ihmiselle haitallisten aineiden jäämiä.

- Hanki tekstiilejä, jotka vastaavat värin kestävyyden ja mittapysyvyyden minimivaatimuksiin.
Kriteerit jaotellaan ydinkriteereihin (vähimmäisvaatimukset) ja kattaviin kriteereihin (tavoitteellisemmat). Ne koskevat:

- torjunta-ainejäämiä luonnonkuituisissa tuotteissa

- kemikaalijäämiä ja aineita, joita voidaan käyttää valmistusprosessissa

- rajoituksia tiettyjen värien käytöstä

- kestävyysominaisuuksia, kuten muodon ja värin pysyvyyttä.

Kriteereihin kuuluvat myös ehdotukset annettavista pisteistä orgaaniselle tuotannolle luonnonkuitujen toimituksessa sekä kierrätettyjen kuitujen osuudesta tuotteessa.

GPP-kriteereissä useimmat rajoitukset vaarallisista kemikaaleista koskevat jäämiä lopullisessa tuotteessa, eivätkä käyttöä tuotannon aikana. Poikkeuksena tässä ovat jotkut värit, jotka GPP-kriteereissä kielletään erityisesti tuotannossa.

Rajoitukset vaarallisten kemikaalien jäämistä lopputuotteessa johtavat usein myös niiden käytön rajoittamiseen tuotannossa. Lisäksi kun pisteitä annetaan orgaanisen puuvillan tuotteiden sisällyttämisestä ja muista orgaanisista luonnonkuiduista, se vähentää torjunta-aineiden käyttöä.

GPP-kriteerit ovat yleisesti vähemmän tiukkoja kuin yleisesti käytetyt ympäristömerkinnät, kuten Joutsenmerkki ja EU-ympäristömerkki (ks. luku 4, sivu 22). GPP-kriteerejä tarkistetaan parhaillaan ja tarkastettua versiota odotetaan vuoden 2017 alussa.

Kansalliset: Kansalliset hankintalaitokset joissakin Pohjoismaissa käyttävät EU-kriteerejä suoraan oppaina tekstiilien hankinnassa, esim. Tanskassa, Norjassa ja Suomessa. 


\section{KANSALLISET HYGIENIASTANDARDIT TERVEYDENHUOLLON PESULOISSA}

Laadittaessa ympäristöä säästävien hankintojen kriteerejä pesulapalveluille hankkijoiden tulee ottaa huomioon näitä palveluita koskevat kansalliset hygienian vähimmäisstandardit.

EU-standardi EN 14065 kuvaa riskinhallinnan menettelytapaa, jolla varmistetaan pesukäsiteltyjen tekstiilien mikrobiologinen jatkuva laatu. Tämä on myös siirretty vastaaviin kansallisiin standardeihin. EN 14065 -standardia on päivitetty äskettäin. Linkit EU-standardiin ja vastaaviin kansallisiin standardeihin löytyvät napauttamalla näistä linkeistä: EU-standardit; tanskalainen versio;

ruotsalainen versio; suomalainen versio: norjalainen versio.

EN 14065 -standardi koskee kohdekynnysarvoja ja hallitsee biologisen saastumisen tarkastuksia ja valvontajärjestelmiä pesujen eri vaiheissa, ennemmin kuin määrittää pesutapoja, joilla vältetään biologinen saastuminen.

Vähintään kolmella Pohjoismaalla on kuitenkin standardit ja ohjeet, jotka määrittävät pesula- ja pesulapalveluiden menettelytavat, joilla vältetään biologinen saastuminen.

- Tanskalainen standardi monikäyttöisten tekstiilien käsittelystä terveydenhuoltosektorilla

- Ruotsalainen käsikirja terveydenhoidon tekstiileistä

- Norjalainen standardi infektioiden hallinnasta pesuloissa, joissa käsitellään terveydenhuollon tekstiilejä. 
Standardit eroavat pesulämpötilavaatimusten suhteen normaalissa lämpödesinfioinnissa. Norjalainen standardi ohjeistaa pesemään 85 asteessa 10 minuutin ajan, tanskalainen standardi 80 asteessa 10 minuutin ajan ja ruotsalainen käsikirja neuvoo 70 asteessa 10 minuutin ajan.

Sekä norjalainen että tanskalainen standardi mahdollistavat alemmat pesulämpötilat, jos käytetään pesuainetta, jolla on sama steriloiva vaikutus. Vastaavuutta tulee valvoa säännöllisesti. Johtavien pesupalveluyritysten mukaan ympäristömerkityt pesuaineet ovat näiden vaihtoehtoisten vaatimusten mukaisia. Tämä myös edistää ympäristövaikutusten vähentämistä verrattuna sterilointiin korkeissa lämpötiloissa.

Ruotsalainen käsikirja on ennemminkin opas kuin vaadittu standardi. Uppsalan sairaalassa tehty tieteellinen tutkimus selvitti, että kun lämpötilaa lasketaan 60 asteeseen, se ei lisää biologisen saastumisen riskiä edellyttäen, että pesun jälkeen tuote kuivataan yli $110 \mathrm{C}$ asteen lämpötilassa pyykinkuivaajassa. Tämä kuitenkin vähentää energian käyttöä kokonaispesussa (Tano ja Melhus, 2014)*.

*Tano, E. ja Melhus, A. (2014) Level of decontamination after washing textiles at $60^{\circ} \mathrm{C}$ or $70^{\circ} \mathrm{C}$ followed by tumble drying. Infect Ecol Epidemiol. 2014 Nov 11;4:24314. 


\section{YHTEISKUNTAVASTUU JA TEKSTIILIEN HANKINTA}

Yhteiskuntavastuu viittaa liiketoimintaan, johon liittyy yhteiskuntaa hyödyttäviä aloitteita. Tähän kuuluvat näissä ohjeissa käsiteltyjen ympäristövaikutusten lisäksi eettiset työkäytännöt, korruptionvastaisuus ja ihmisoikeudet. Nämä tekijät ovat merkittäviä hankittaessa terveydenhuollon tekstiilejä. Joissakin Pohjoismaissa tämä on ollut painopisteessä usean vuoden ajan.

Esimerkiksi Ruotsissa kaikilla alueilla on yhteinen menettelytapa, johon toimittajien tulee sitoutua ja heidän tulee vastata vaatimustenmukaisuuskysymyksiin. Menettelytapa perustuu YK:n yleiseen ihmisoikeusjulistukseen, ILO:n yleissopimukseen, YK:n lastenoikeuksien julistukseen, YK:n korruption vastaiseen julistukseen ja soveltuvaan työja ympäristölainsäädäntöön tuotantomaassa. Menettelytapa löytyy tästä linkistä.

Ruotsalaisilla alueilla on saatavilla myös yhteiset verkkoportaalioppaat ja tietoja yhteiskuntavastuusta, missä tekstiilejä pidetään yhtenä yhdeksästä riskialueesta terveydenhuollon hankinnoissa. Määrätyt alueet ovat vastuussa noudattamisesta ja tarkastuksia tiettyihin tuoteryhmiin ja tekstilintuotantoon on tehty viime vuosina esim. Intiassa ja Pakistanissa. Riskiarviointi löytyy tästä linkistä.

Tanskan hankintaviranomainen huomioi lisäksi eettiset ja ympäristöperiaatteet joihin kuuluvat osittain Global Compact -periaatteet.

Norjan laitos huomioi myös eettiset tekijät muun muassa edistämällä aloitteita, jotka on kohdistettu huonojen työolosuhteiden huomioimiseen tekstiilien valmistuksessa: Better Cotton -aloite, Clean Clothes -kampanja, ACCORD ja IPEC. Näistä käyttökelpoisimpia hankkijoiden käyttöön ovat Better Cotton -aloite ja ACCORD, koska niistä voidaan nähdä, mitkä brändit/valmistajat ovat mukana aloitteissa. Siitä ei kuitenkaan ole takuuta, että näiden jäsenien valmistamat vaatteet (ainakaan vielä) olisivat aloitteiden periaatteiden ja tavoitteiden mukaisia.

EU-ympäristömerkki, Joutsenmerkki ja Bra Miljöval sisältävät kriteerit, joissa huomioidaan työntekijöiden oikeudet tekstiilien valmistuspaikassa, (ks. luku 4, sivu 22).

Muita hyödyllisiä linkkejä:

- World Wide Responsible Apparel

- CSR compass 
Ruotsin kansallisella julkisten hankintojen laitoksella on verkkoresurssi, joka sisältää sekä ohjeet että kattavan tausta-asiakirjan, jossa kuvataan tekstiilien käytön ympäristövaikutuksia, määräyksiä liittyen kemikaalien käyttöön tekstiilintuotannossa, ja lopuksi siinä luetellaan haitalliset kemikaalit ja aineet, joita tulisi rajoittaa tarjouspyynnössä määritellyissä kriteereissä. Tämä kemikaaliluettelo on kattavampi kuin EU:n GPP-kriteereissä oleva, ja se on lähellä EU-ympäristömerkissä ja tekstiileille tarkoitetussa Joutsenmerkissä käytettyjä kemikaaleihin liittyviä kriteerejä.

Päinvastoin kuin muissa laitoksissa, Ruotsin kansallinen julkisten hankintojen laitos tarjoaa myös tausta-asiakirjan ja opastusta hankintojen pesulapalveluille. Ne kattavat useita kohtia, jotka koskevat kemikaalien ja pesuaineiden käyttöä ja hallintaa pesuprosesseissa ja pesupalveluiden energian ja vedenkulutusta ja ilmaan joutuvia päästöjä.

EU:n ja kansalliset GPP-kriteerit voivat ylittyä sellaisten tekstiilien kohdalla, joilla on Joutsenmerkki,
EU-ympäristömerkki tai Bra Miljöval -merkki. Ruotsalaiset kriteerit pesulapalveluille täyttyvät tekstiilipalveluissa, joilla on Joutsenmerkki (ks. luku 4, sivut 22 - 24).

Vaikkei asia tämän oppaan kohdealueeseen kuulukaan, alla oleva laatikko tarjoaa myös resursseja eettisten kriteerien sisällyttämiseksi hankintaprosesseihin.

Hankkijoiden täytyy valita kriteerit, jotka sopivat heidän tarpeisiinsa ja ympäristöön liittyviin (ja eettisiin) tavoitteisiinsa. Sivuilla 20 - 21 on kokoelma peruskriteereitä, joita Norjan keskushankintayksikkö Sykehusinnkjøp HF on käyttänyt äskettäin tehdyissä työasuja koskevassa tarjouskilpailussa. Tarjouskilpailuperusteisiin liittyy myös haitallisia kemikaaleja sisältäviä poistotekstiilejä koskevia lisäkriteerejä, sekä tuotteiden pakkaamista koskevat kriteerejä. Kriteerit eivät ole niin kattavia kuin EU:n GPP-kriteerit

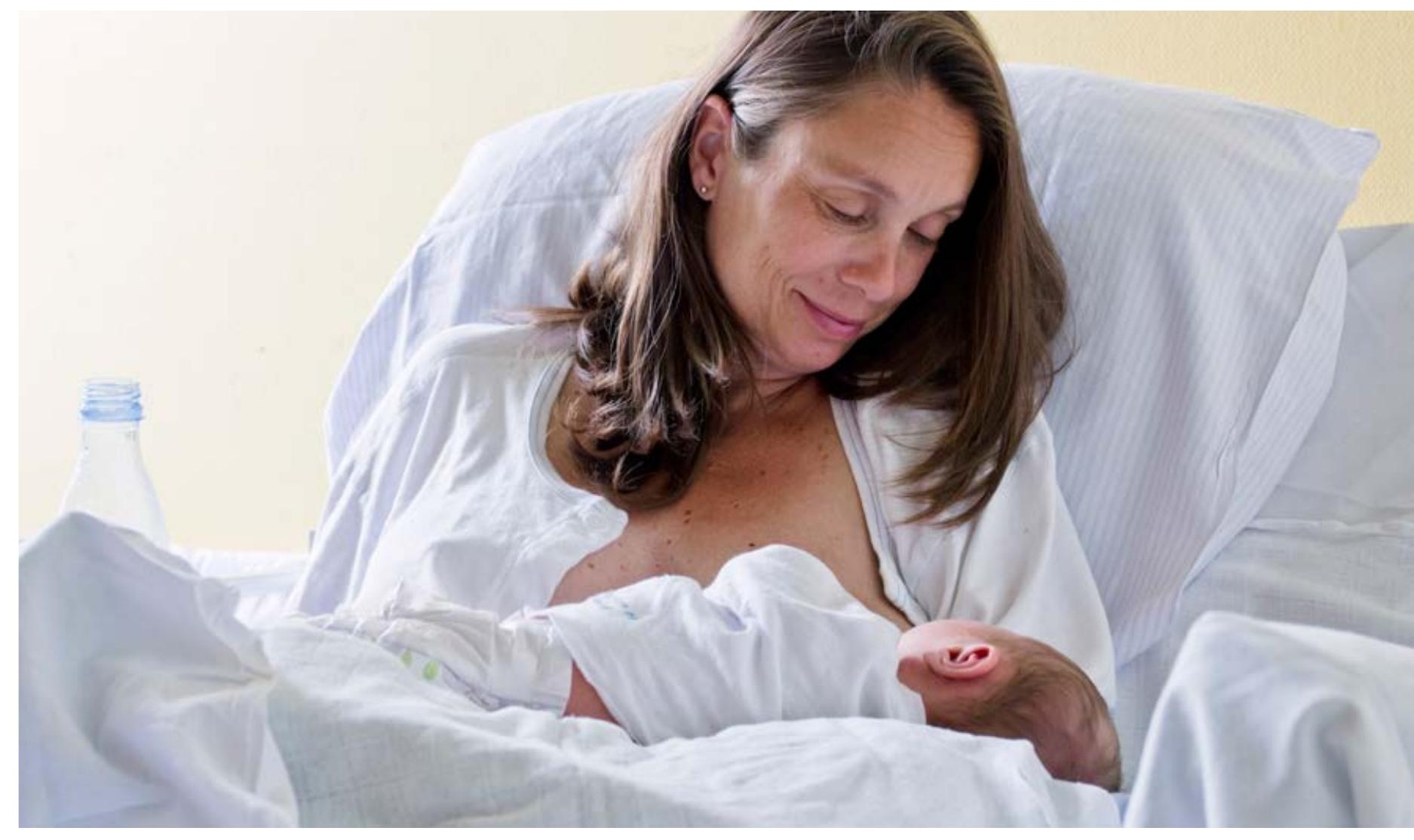




\section{Esimerkki kriteereistä, joita käytetään henkilöstön työasujen kilpailutuksessa}

\section{KEMIKAALIEN VÄHIMMÄISVAATI- MUKSET}

\section{Lain vaatimuksien noudattaminen}

Tarjottujen tuotteiden täytyy olla haitallisia kemikaaleja ja muita tuotteita koskevien määräysten rajoitusten mukaisia (Tuotemääräykset FOR2004-06-01- 922). Tarjottujen tuotteiden täytyy olla REACH-asetuksen kemikaaleja koskevan lainsäädännön vaatimusten mukaisia.

\section{Yleiset vaatimukset:}

Tuotteet eivät saa sisältää aineita, joita on EU:n listalla tai norjalaisella prioriteettilistalla. Tämä koskee myös apukemikaaleja ja pesuaineita.

\section{Torjunta-aineiden käyttö}

Tuotteiden, votteissa, jotka on valmistettu puuvillasta tai muista luonnollisista selluloosakuiduista, lopputuotteet eivät saa sisältää 0,05 ppm enempää seuraavista aineista, eikä kokonaispitoisuus saa ylittää 0,75 ppm:

2,4,5-T, aldriini, kaptafoli, klordaani, klordimeformi, DDT, dieldriini, dinosebi suoloilla, endriini, heptakloori, hek- saklooribentseeni, heksaklorsykloheksaani, $\alpha$, heksaklorsykloheksaani, $\beta$, heksaklorsykloheksaani, $\delta$, metamidofoosi, monokrotofoosi, parationi, metyyliparatiooni, propetampoosi, toksafeeni.

\section{Palamisenestoaineet}

Hankituissa vaatteissa ei saa olla kemiallisia palamisenestoaineita, ellei se ole ehdottoman tarpeellista johtuen tekstiilien funktiosta. Jos palamisenesto-ominaisuus vaaditaan, se tulee mainita tarjouspyynnössä. Tällöin täytyy käyttää fosfori- ja/tai typpipohjaisia orgaanisia yhdisteitä tai palamisenestoaineita, joilla on vastaavat tai paremmat terveys- ja ympäristöominaisuudet. Halogenoituja palamisenestoaineita ei saa käyttää missään olosuhteissa.

\section{Alkyylifenolietoksylaatit}

Tuote ei saa sisältää alkyylifenolietoksylaatteja. (Nonyylilfenoli on rajoitettu REACH-asetuksen liitteessä XVII ja prioriteettilistalla, mutta sitä voi tästä huolimatta esiintyä tuotteissa.) 


\section{LAADUN VÄHIMMÄISVAATIMUKSET}

\section{Mittamuutokset pesun ja kuivauksen aikana}

Rajoitukset mittojen muutoksille pesun ja kuivauksen jälkeen:

+/- 3 \% puuvillasta ja puuvillaseoksesta kudotut tuotteet

+/- 2 \% kuitutuotteet, joissa on villasekoitusta ja synteettisiä kuituja.

$+/-4 \%$ neuleet.

$+/-6 \%$ karkeat neuleet (iso neulos).

$+/-5 \%$ neuleet (Interlock).

+/- $7 \%$ froteepyyhkeet ja resorituotteet.

Vaatimus ei koske kuituja tai lankoja, tuotteita, jotka on merkitty selvästi "vain kuivapesu", tai vastaavia. Testit tulee suorittaa standardien EN ISO 6330, ISO 5077 tai vastaavan mukaisesti. Testauksessa noudatetaan seuraavaa menettelytapaa: Pese tuote kolmesti tuotteessa ilmoitetun lämpöisellä vedellä, ja kuivaa tuote sen jälkeen kuivausrummussa, ellei tuotteessa ole ilmoitettu muuta kuivatustapaa.

\section{Värin kesto pesussa (pesunkesto)}

Pesunkeston tulee olla vähintään tasoa 3 - 4 värimuutoksille ja vähintään tasoa 3 - 4 värin tarttumiselle. Vaatimus ei koske tuotteita, jotka on merkitty selvästi "vain kuivapesu" tai vastaavia, valkopyykkiä tai tuotteita, joita ei ole värjätty tai painettu. Testi tulee suorittaa standardin EN ISO 105-CO6 tai vastaavan mukaisesti. Tämä tarkoittaa yksittäistä pesua tuotteessa merkityssä lämpötilassa.

\section{Märkähankauksen kesto}

Märkähankauksen keston tulee olla vähintään tasoa 2 - 3. Vaatimus ei koske valkopyykkiä tai tuotteita, joita ei ole värjätty tai painettu. Testi tulee suorittaa standardin ISO 105 X12 tai vastaavan mukaisesti.

\section{Kuivahankauksen kesto, kuiva}

Värin kesto kuivana hangattaessa tulee olla vähintään tasoa 4. Vaatimus ei koske valkopyykkiä tai tuotteita, joita ei ole värjätty tai painettu. Testi tulee suorittaa standardin ISO $105 \times 12$ tai vastaavan mukaisesti.

\section{MYÖNTÄMISEDELLYTYKSET}

\section{Orgaaninen puuvilla tai muut luonnonkuidut}

Lisäpisteitä annetaan orgaanisesti kasvatetun puuvillan tai muiden luonnonkuitujen paino-osuuden mukaisesti. Jotta kuituja voidaan pitää orgaanisina, niiden täytyy olla viljeltyjä seuraavan asetuksen mukaisesti: neuvoston asetus (EY) 834/2007, 28.6.2007 luonnonmukaisesta tuotannosta ja luonnonmukaisesti tuotettujen tuotteiden merkinnöistä sekä asetuksen (ETY) No. 2092 / 91 kumoamisesta. 
Luku 4

\title{
Pikakatsaus ympäristömerkkeihin
}

\author{
Ympäristömerkinnän sisällyttäminen tarjouskilpailuun vaatii huolellista pohdiskelva \\ ja tietämystä siitä, mitä ympäristömerkintä koskee. Valitse ympäristömerkintä, joka \\ sopii omiin ympäristöä koskeviin tavoitteisiisi, mutta varo rajoittamasta mahdollisten \\ toimittajien määrää liikaa. Voi olla, että mikään ympäristömerkki ei kata kaikkia \\ tärkeitä ympäristöasioita, ja voit haluta ottaa mukaan lisävaatimuksia.
}

Vuodesta 2014 lähtien EU:ssa voimassa olleen lain mukaan ympäristömerkki voidaan ottaa suoraan julkisten hankintojen vaatimukseksi, mutta tämä koskee vain niitä ympäristömerkkejä, jotka vastaavat tiettyjä raportointi- ja laatumääräyksiä (ks. luku 3.5.1 Buying Green! -käsikirjassa). Tämä uusi sääntö auttaa hankinnan tekijöitä ympäristövaatimusten asettamisessa, ja toimittajat pystyvät varmistamaan, että he pystyvät täyttämään kriteerit. Tanskassa hankinnan tekijöiden tulee kuitenkin sallia toimittajat, joiden tuotteet voisivat olla kriteerien mukaisia, mutta jotka eivät ole saaneet vielä ympäristömerkkiä. Toimittajilta tulee saada dokumentaatio tästä tunnin kuluessa, mistä aiheutuu lisäpainetta hankintayksikölle.

Tekstiilituotteille on saatavilla monia merkkejä, mutta vain Joutsenmerkkiin kuuluu tekstiilipalveluja koskevat vaatimukset. Terveydenhuollon tekstiilituotteita koskevia ympäristömerkkejä ovat Joutsenmerkki, EU-ympäristömerkki (joskus myös EU-kukka), GOTS (Global Organic Textile Standard) ja ruotsalainen Bra Miljöval (Hyvä ympäristövalinta). Vaikkei Oeko-Tex 100 ole tiukasti pelkkä ympäristömerkki, se mainitaan joskus myös ympäristöä säästävissä hankintakriteereissä. BlueSign-merkintä on edelleen ainoa ulkokäyttöön tarkoitetuissa tuotteissa käytettävä merkintä ja sen vuoksi se ei vielä koske sairaalojen hankintayksiköitä, ellei ajatella mahdollisia ulkotyöasuja.

Huomaa, että kaikki ympäristömerkinnät eivät noudata EU-komission asettamia kriteerejä Buying Green! -käsikirjassa, joka sallii niiden käytön hankinta-asiakirjoissa.
Alla olevassa taulukossa vertaillaan ympäristötekijöitä useimpien merkkien näkökulmasta. Kaksi merkkiä tarkoittaa tiukempia ja/tai kattavampia kriteereitä kuin yksittäinen merkki.

Myös Ruotsin julkisten hankintojen laitos on verrannut näiden merkkien tiettyjen kemikaalien ja aineiden rajoituksia, asiakirja löytyy tästä linkistä.

Oeko-Tex -merkin tavoite on suojata tekstiilien käyttäjiä vaarallisilta kemikaalijäämiltä vaatetuksessa ja tekstiileissä, jotka laitetaan myyntiin. Kemikaalirajoitukset kohdassa muut ympäristömerkit koskevat koko käyttöikää ja pyrkivät vähentämään ympäristöjärjestelmiin ja inmisiin kohdistuvia vaikutuksia koko arvoketjussa, mukaan lukien loppukäyttäjät. Oeko-Tex on julkaissut merkin (STeP), joka kattaa tuotannon ympäristötekijät, mutta tämä on ennemminkin tuotantopaikoille tarkoitettu ympäristönhallinnan tyyppinen merkki kuin tuotteisiin liittyvä merkki. Sillä on siten rajoitettu merkitys hankkijoille.

Joutsenmerkillä on myös merkintä ja kriteerit tekstiilipalveluille. Merkkiin liittyy erityisvaatimus sairaalatekstiilien pesusta, mikä on huomioitava hygieniastandardeissa. Vaatimukset koskevat energian ja vedenkäyttöä ja pesuaineita/kemikaaleja pesuloissa ja pakkauksissa ja kuljetusta logistiikassa. Merkki sisältää myös vaatimuksen ympäristömerkkien vähimmäisosuudesta tekstiilipalvelun vuokraamissa tuotteissa. 


\section{Pikavertailu tekstiilituotteiden merkinnöistä}

\begin{tabular}{|c|c|c|c|c|c|}
\hline & $\begin{array}{l}\text { Joutsen- } \\
\text { merkki }\end{array}$ & $\begin{array}{l}\text { EU- } \\
\text { ympäristömerkki }\end{array}$ & Bra Miljöval & $\begin{array}{l}\text { GOTS (vain } \\
\text { luonnolliset } \\
\text { kuidut) }\end{array}$ & $\begin{array}{l}\text { Oeko-tex } \\
100\end{array}$ \\
\hline $\begin{array}{l}\text { Orgaanisen materiaa- } \\
\text { lin osuus (lvonnolliset } \\
\text { kuidut) }\end{array}$ & $\checkmark$ & $\checkmark$ & $\checkmark \checkmark$ & $\checkmark \checkmark$ & \\
\hline Kierrätetty sisältö & $\checkmark$ & $\checkmark$ & $\checkmark$ & & \\
\hline $\begin{array}{l}\text { Kemikaalien rajoitukset } \\
\text { tuotantoprosesseissa }\end{array}$ & $\checkmark \checkmark$ & $\checkmark \checkmark$ & $\checkmark \checkmark$ & $\checkmark \checkmark$ & \\
\hline $\begin{array}{l}\text { Rajoitukset tuotteen } \\
\text { kemikaalijäämistä }\end{array}$ & $\checkmark \checkmark$ & $\checkmark \checkmark$ & & $\checkmark \checkmark$ & $\checkmark \checkmark$ \\
\hline Poistoveden hallinta & $\checkmark \checkmark$ & $\checkmark \checkmark$ & $\checkmark \checkmark$ & $\checkmark \checkmark$ & \\
\hline $\begin{array}{l}\text { Vähemmän } \\
\text { ilmansaasteita }\end{array}$ & & $\checkmark$ & $\checkmark \checkmark$ & & \\
\hline $\begin{array}{l}\text { Vähemmän kiinteää } \\
\text { jätettä }\end{array}$ & & & $\checkmark$ & $\checkmark$ & \\
\hline $\begin{array}{l}\text { Tuotteen laatu ja } \\
\text { kestävyys }\end{array}$ & $\checkmark$ & $\checkmark$ & & $\checkmark$ & \\
\hline Pakkausmateriaalit & $\checkmark$ & & $\checkmark \checkmark$ & $\checkmark \checkmark$ & \\
\hline $\begin{array}{l}\text { Työntekijöiden oikeudet/ } \\
\text { työolosuhteet }\end{array}$ & $\checkmark \checkmark$ & $\checkmark \checkmark$ & $\checkmark \checkmark$ & & \\
\hline $\begin{array}{l}\text { Sertifikaatti } \checkmark \checkmark 3 \text {. } \\
\text { osapuoli } \checkmark 2 \text {. osapuoli }\end{array}$ & $\checkmark \checkmark$ & $\checkmark \checkmark$ & $\checkmark \checkmark$ & $\checkmark \checkmark$ & $\checkmark \checkmark$ \\
\hline
\end{tabular}

Lähde: Planmiljøn tekemä vertailu

Hankintayksikkö voi asettaa myös muita vaatimuksia, joihin voi saada inspiraatiota ympäristömerkkejä koskevista vaatimuksista. Tekstiilipalvelujen toimittaja voi esimerkiksi saada pohjoismaisen Joutsenmerkin, jos hän täyttää vähimmäisvaatimukset ja saa lisäksi 15 pistettä 65:stä valinnaisissa vaatimuksissa. Kunnianhimoisempi hankintayksikkö voi asettaa palveluntarjoajan valinnaisille vaatimuksille korkeamman kynnyksen, esim. 25 pistettä.

Ennen kuin ympäristömerkkejä käytetään tiettyä tuotetta koskevassa tarjouspyynnössä, on varmistettava, että vähintään kaksi tai kolme toimittajaa pystyy toimittamaan vaatimusten mukaisia tuotteita. Muutoin hinta voi nousta liian korkeaksi. Useimmilla ympäristö- merkeillä on luettelo tuotteista, jotka on sertifioitu eri kategorioissa. Se auttaa myös neuvottelumenettelyyn ryhtymistä (ks. luku 2, sivut 10 - 12).

Ympäristömerkkien kriteerit löytyvät alla olevista linkeistä:

- Joutsenmerkityt tekstiilit

- Joutsenmerkityt tekstiilipalvelut

- EU-ympäristömerkki tekstiileille

- Bra Miljöval

- GOTS

- Oeko-tex 100 


\section{Luku 5}

\section{Kuidun valinta}

Oikealla kuituvalinnalla saadaan monella tavalla merkittäviä ympäristöhyötyjä.

Kuituvalinta voi vaikuttaa esim. pesun energiankäyttöön, tuotteen kestävyyteen ja

tuotannon ympäristövaikutuksiin. Kuituvalinta on tärkeä myös käyttömukavuuden ja

hygienian kannalta.

Kun valitaan kuitua tekstiileihin, on tärkeää huomioida kuitujen ominaisuudet ja niihin liittyvät ympäristövaikutukset. Esimerkiksi:

\section{- Eri kuiduilla on erilaiset ympäristöprofiilit} tuotannon aikana: alla oleva taulukko on tehty käyttämällä elinkaarianalyysia. Puuvillalla ja polyesterillä on suuremmat tuotantoon kohdistuvat vaikutukset kuin joillakin uusilla kuiduilla. Myrkyllisyysvaikutukset eivät sisälly kaavioon, ja ne asettaisivat puuvillan hieman huonompaan valoon johtuen torjunta-aineiden suurimittaisesta käytöstä perinteisessä puuvillan viljelyssä. Myrkyllisyysvaikutuksia voidaan vähentää käyttämällä orgaanista puuvillaa.

\section{- Jotkut kuidut ovat kestävämpiä kuin muut:} polyesteri tai polyesteri/puuvilla-sekoitus voi kestää useampia pesuja kuin $100 \%$ puuvilla ${ }^{3}$. Viimeistelyaineen lisääminen voi myös pidentää käyttöikää.

- Synteettisiä kuituja on helpompi pestä, koska ne imevät vähemmän vettä ja niiden konekuivaukseen tarvitaan vähemmän energiaa. Uudet tutkimukset osoittavat myös, että niitä voidaan pestään alemmissa lämpötiloissa kuin puuvillaa hygieniasta tinkimättä, vaikkei tätä ole mainittu nykyisissä kansallisissa hygieniastandardeissa.

- Puhtaita kuituja ja synteettisiä kuituja on helpompi kierrättää käytön jälkeen: $100 \%$ polyesteriä voidaan teoriassa kierrättää loputtomasti uusiksi tekstiileiksi. 100 \% puuvillaa voidaan myös kierrättää käyttöön uusissa tekstiileissä, mutta siihen tulee sekoittaa $80 \%$ uutta puuvillaa, jotta tekstiili säilyttää laatunsa. Kuituseosten kierrättäminen on vaikeampaa kuin esim. polyesterin/puuvillan. On tärkeää, että sairaalatekstiilien kierrätysstrategiassa ei tingitä kestävyydestä. Pidempi käyttöikä tarjoaa paljon suuremmat ympäristöhyödyt kuin kierrätys.

- Synteettisten kuitujen mikromuovit voivat saastuttaa meriä, vaikka saastumislähteenä ne ovat pienempi kuin esim. autonrenkaat. Tämän ongelman oletetaan poistuvan tulevaisuudessa, kun saadaan kehitettyä pesuloihin asennettavat erityiset jätevesisuodattimet ${ }^{4}$.

${ }^{3}$ http://www.howstuffcompares.com/doc/c/cotton-vs-polyester.htm

${ }^{4}$ http://www.plasticsouplab.org/showcases/washing-machine-filter/ 
Elinkaarivaikutusten vertailu eri kuitujen välillä

\begin{tabular}{|c|c|c|c|c|c|}
\hline & Energy use & Water use & $\begin{array}{l}\text { Greenhouse } \\
\text { gasses }\end{array}$ & Waste water & $\begin{array}{l}\text { Direct land } \\
\text { use }\end{array}$ \\
\hline $\begin{array}{l}\text { Decreasing } \\
\text { environment al } \\
\text { impact }\end{array}$ & $\begin{array}{l}\text { Acrylic } \\
\text { Nylon } \\
\text { Polyester/ } \\
\text { PTT } \\
\text { Regen. } \\
\text { cellulosic } \\
\text { (viscose, } \\
\text { Modal) } \\
\text { PLA/ } \\
\text { Cotton/ } \\
\text { Lyocell } \\
\text { Wool } \\
\text { Natural } \\
\text { bast fibres } \\
\text { (nettle, } \\
\text { hemp, flax) }\end{array}$ & $\begin{array}{l}\text { Cotton } \\
\text { Silk } \\
\text { Nylon } \\
\text { Regen. } \\
\text { cellulosic } \\
\text { Acryl } \\
\text { Hemp } \\
\text { Wool } \\
\text { Natural bast } \\
\text { fibres } \\
\text { Polyester }\end{array}$ & $\begin{array}{l}\text { Nylon } \\
\text { Polyester } \\
\text { Lyocell } \\
\text { PLA } \\
\text { Viscose } \\
\text { Modal } \\
\text { Cotton } \\
\text { Natural bast } \\
\text { fibres } \\
\text { Wool }\end{array}$ & $\begin{array}{l}\text { Wool } \\
\text { Regen. } \\
\text { cellulosic } \\
\text { Natural bast } \\
\text { fibres } \\
\text { Nylon } \\
\text { Polyester }\end{array}$ & $\begin{array}{l}\text { Wool } \\
\text { Ramie } \\
\text { Cotton } \\
\text { Flax } \\
\text { Hemp } \\
\text { Viscose } \\
\text { and Modal } \\
\text { Jute } \\
\text { PLA } \\
\text { Lyocell }\end{array}$ \\
\hline
\end{tabular}

Lähde: EU:n tekninen taustaraportti tekstiilien GPP-kriteereille 2011

Käytetyn kuidun täytyy myös täyttää muut vaatimukset, ei pelkästään hygieniastandardeja (esim. infektionhallinta leikkaussalin tekstiileissä, ks. luku 6, sivut 28 - 29) ja käyttömukavuusvaatimuksia.

\section{Miellyttävyys: onko puuvilla todella paras?}

Ympäristöhaitoista huolimatta hoitohenkilöstö ja potilaat voivat pitää puuvillaa halutuimpana materiaalina sen käyttömukavuuden vuoksi. Tämä voi kuitenkin perustua pikemminkin ennakko-oletuksiin kuin todellisiin kokemuksiin.

Miellyttävyyttä testaavat laboratoriotestit käyttävät vakioituja testaustekniikoita, ja ne mittaavat:
- lämmönkestoa

- vesihöyryn kestävyyttä

- ilman läpäisevyyttä

- pintakitkaa ja karheutta (Kawabatan arviointijärjestelmä)

- kosteuden hallintaa (AATCC-standardi)

- vetolujuutta

Ennakko-oletusten murtamiseksi voi kuitenkin kannattaa toteuttaa henkilöstön ja potilaiden käyttötestejä saatavilla oleville materiaaleille ennen lopullisen valinnan tekemistä. Käyttäjätestaus voi johtaa löydöksiin, joissa vaihtoehtoiset kuidut ovat mukavampia käytössä, samalla kun niistä on ympäristö- ja taloudellisia etuja ${ }^{5}$. Katso esimerkki sivulla 26 kuvatusta pilottiprojektista, jossa saatiin juuri tällainen tulos.

${ }^{5}$ http://www.greenercleaner.net/natural-or-synthetic-textiles/ 


\section{TYÖASUJEN INNOVATIIVINEN HANKINTA RAWICZIN SAIRAALASSA}

Vuonna 2011 Rawiczin kunnan sairaala Puolassa osallistui LCB-terveydenhuollon verkostoon, joka oli EU:n rahoittama verkosto innovatiivisille hankinnoille. Sairaalassa lanseerattiin pilottina innovaatiohankintaprojekti, jossa keskityttiin henkilöstön työasujen kestävämpään hankintaan.

Pilottiprojekti alkoi konsultoimalla sairaanhoitajia, lääkäreitä ja muuta henkilöstöä työasujen käyttöominaisuuksista. Tämä antoi päätösvaltaa henkilöstölle, joka kiinnitti huomiota seuraaviin: uusien työasujen tuli olla toimivia, kivan näköisiä, helppokäyttöisiä, helppoja puhdistaa, kestäviä ja kustannustehokkaita.

Näiden toiminnallisten tulosten määrittäminen hankinta-asiakirjoissa materiaalin, kuitutyypin, suunnittelun jne. määrittämisen sijaan antoi hankkijoille ja toimittajille mahdollisuuden tutkia innovatiivisempia ratkaisuja. Lisäksi, kun kahdeksan muuta puolalaista sairaalaa kiinnostui pilottiprojektin tuloksista, saatiin tarjouksia useammilta toimittajilta.

Sairaala kertoi tarpeensa ja markkinoiden vaatimukset oma-aloitteisesti, ja potentiaalisille toimittajille pidettiin avoin kokous. Palaute oli hyvin positiivista, ja avoimet määrittelyt antoivat toimittajille mahdollisuuden tuoda tuotteensa esiin myös muihin tekijöihin kuin pelkästään hintaan perustuen. Erityisesti elinkaarikustannukset (TCO ks. luku 7, sivut 30 - 31) saivat etusijan alkuperäisiin hankintakustannuksiin verrattuna arvioitaessa toimittajilta saatuja tarjouksia.

Neuvottelumenettelyn ja hankintaprosessin tuloksena olivat työasut, jotka valmistettiin polyesterin ja tenselin (eucalyptus-pohjainen tuote) seoksesta. Materiaaliseosta pidettiin kestävänä pesun aikana, nopeampana kuivata, tahrankestävämpänä ja se sai yleisesti kiitosta laadustaan ja toimivuudestaan. Vaikka alkuperäinen hankintahinta oli korkeampi kuin muutamissa kilpailevissa tarjouksissa, sillä oli halvimmat kokonaiskustannukset johtuen pienemmistä pesukuluista ja pidemmästä käyttöiästä.

Lisätietoja saat ottamalla yhteyttä Marcin Kautschiin sähköpostilla: mxkautsc@wp.pl 


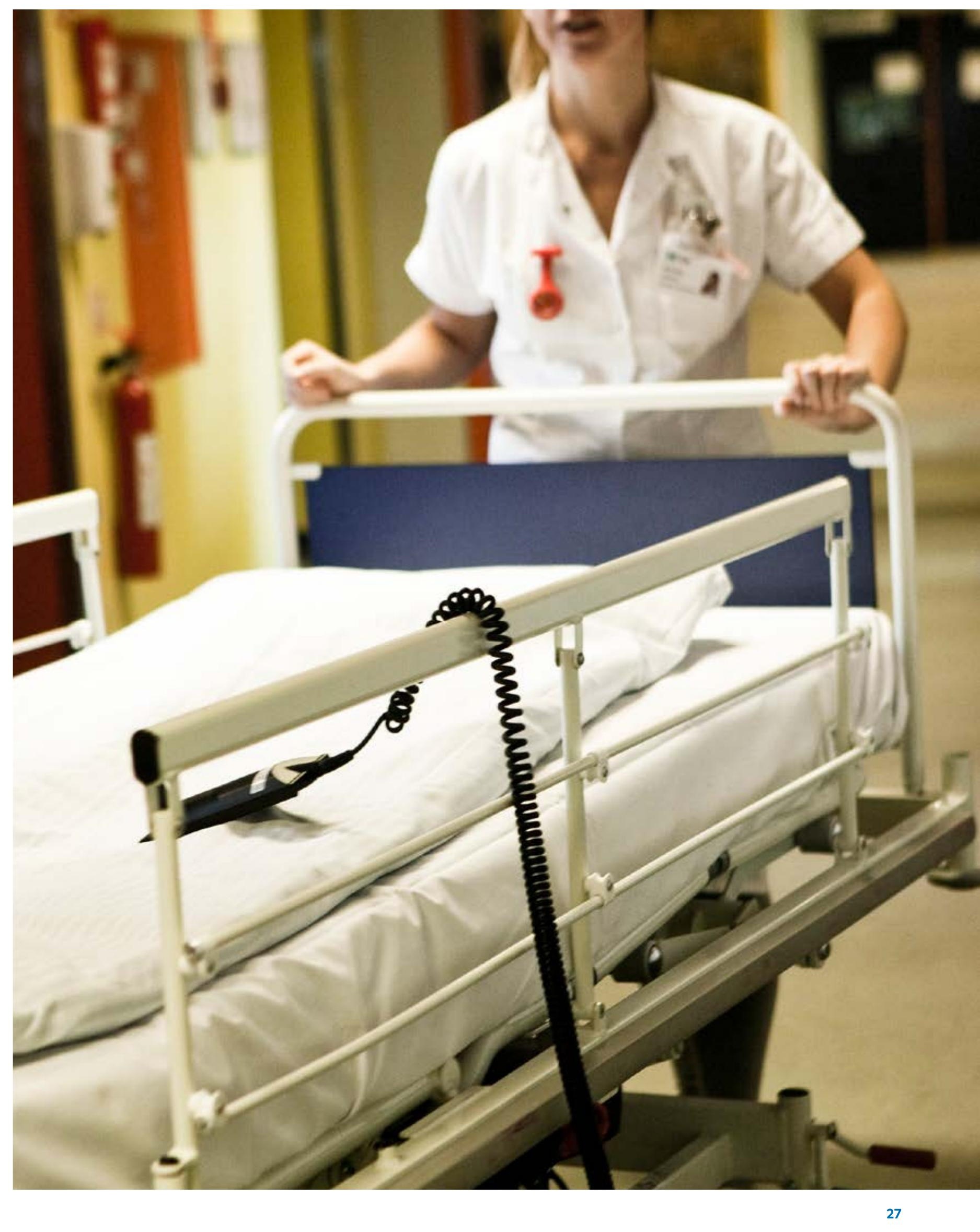


Luku 6

\section{Kertakäyttöiset vs. monikäyttöiset tekstiilit}

Kertakäyttöisillä, ei-kudotvilla ja monikäyttöisillä tekstiilituotteilla on etuja ja haittoja. Tämä koskee erityisesti leikkaussalitekstiileitä, joiden infektion hallinta on ehdottoman tärkeää. Hygienian lisäksi muita tärkeitä muuttujia ovat kokonaiskulut käyttökertaa kohden, toimivuus ja käyttömukavuus sekä tärkeimpänä ympäristövaikutukset.

Kertakäyttöiset ja modernit monikäyttöiset leikkaussalitekstiilit ovat suurin piirtein vastaavia suojaavuudeltaan, mikä on ratkaiseva tekijä infektioiden hallinnassa. Tämä riippuu hyväksyttyjen menettelytapojen mukaisesti pestävistä ja steriloiduista monikäyttöisistä tekstiileistä.

Ilman kautta kulkeutuvien partikkelien vapautumisen minimointi on myös tärkeää infektioiden hallinnassa. Uudenaikaisista monikäyttöisistä barrierikankaista, jotka on valmistettu filamenttilangoista, irtoaa paljon vähemmän nukkaa kuin perinteisistä puuvillakuiduista, ja ne toimivat yhtä hyvin kuin kertakäyttöiset kuitutuotteet. Ne ovat myös hengittäviä ja mukavia käyttää.

Tutkimustulokset liitetään kertakäyttöisen tuotteen kustannuksiin ja vertailu on hyvin maakohtainen.

Suuremmat työvoimakustannukset voivat edistää kertakäyttöisten tuotteiden valintaa, kun taas hävityskustannukset puhuvat useampikäyttöisten tuotteiden puolesta.
Toisaalta useat tutkimukset ovat selvittäneet, että monikäyttöisillä tekstiileillä on enemmän ympäristöhyötyjä kuin kertakäyttöisillä 6,7,8,9. Kuudessa käyttöikäarviossa selvitettiin, että kertakäyttöisillä leikkaussalitekstiileillä on 2 - 3 -kertainen hiilijalanjälki, ja ne käyttävät 2 - 3 kertaa enemmän energiaa ja vettä käyttökertaa kohden kuin uudenaikaiset, monikäyttöiset tekstiilit ${ }^{10}$. Koska modernit monikäyttöiset tekstiilit ovat parempia tai verrattavissa muissa suhteissa kertakäyttöisiin, ne vaikuttavat olevan kestävämpi valinta.

Uudelleen käytettävien leikkaussalitekstiilien käyttö riippuu siitä, onko sairaalalla kapasiteettia steriloida kestokäyttöisiä leikkaussalimateriaaleja.

Seuraavia ohjeita voidaan antaa sairaaloille ja niiden pesulapalveluille, jotka haluavat vaihtaa kertakäyttöisistä kestokäyttöisiin leikkaussalitekstiileihin ${ }^{11}$ :

\footnotetext{
${ }^{6}$ Overcash (2012) A Comparison of Reusable and Disposable Perioperative Textiles: Sustainability State-of-the-Art 2012 http://www.ncbi.nlm.nih.gov/pubmed/22492184

${ }^{7}$ Carre (2008) LCA Comparing Laundered Surgical Gowns with Polypropylene Based Disposable Gowns http://trlaa.com.au/wordpress/wp-content/uploads/Lifecycle_Assessment_Study.pdf

${ }^{8}$ Mikusinska (2012) Comparative Life Cycle Assessment of Surgical Scrub Suits

http://kth.diva-portal.org/smash/get/diva2:574013/FULLTEXTO1.pdf

${ }^{9}$ Eriksson och Berg (2003) Livscykelanalys av Operationsrockar

http://www.vgregion.se/upload/Tv\%C3\%A4tteriet\%2OAlings\%C3\%A5s/LCA\%2Ooperationsrockar_granskad.pdf

${ }^{10}$ Overcash (2012) A Comparison of Reusable and Disposable Perioperative Textiles: Sustainability State-of-the-Art 2012 http://www.ncbi.nlm.nih.gov/pubmed/22492184

${ }^{11}$ https://americanlaundrynews.com/articles/winning-sale-reusable-surgical-textiles-part-1
} 
Uudelleenkäytettävien ja kertakäyttöisten leikkaussalitekstiilien vertailu

\begin{tabular}{|l|c|c|c|}
\hline & Cotton reusable & Disposables & High tech reusable \\
\hline Barrier effect & - & + & + \\
\hline Cleanliness & + & - & + \\
\hline Particle emission & - & - & + \\
\hline $\begin{array}{l}\text { Comfort and } \\
\text { breathability }\end{array}$ & + & - & + \\
\hline Environmental impact & $+/-$ & + & + \\
\hline Functionality & - & $+/-$ & $+/-$ \\
\hline Cost effective & $+/-$ & $+/-$ & + \\
\hline Value for money & - & $?$ & + \\
\hline
\end{tabular}

Lähde: Petel, M. (2014) $)^{12}$

Aloita pienestä. Aloita hallittavissa olevalla suunnitelmalla, esim. leikkaussalipyyhkeillä ja kirurgien esiliinoilla.

1. Työskentele kestokäyttöisiä leikkaussalitekstiilejä tarjoavan toimittajan kanssa. Merkitse muistiin toimittajan tarjoamat tiedot ja resurssit. Ota yhteyttä pesuloihin, jotka ovat saaneet sairaalat käyttämään uudelleenkäytettäviä materiaaleja.

2. Valmistele luonnos, jossa verrataan kertakäyttöisiä tuotteita kestokäyttöisiin vaihtoehtoihin. Tähän vertailuun tulisi liittää kulut, tuote- ja barrieriominaisuudet, sterilointi, hävityskulut, toimitus, henkilöstömäärä ja kaikki muut palvelut, joita pesula kykenee tarjoamaan.

3. Kun sinulla on alkusuunnitelma, perusta monitieteellinen tiimi.
4. Järjestä tiimille (ympäristöviranomaisille, sairaalahenkilöstölle ja päätöksentekijöille) kierros pesulaja pakkaustiloihin.

5. Aloita muutaman viikon kestävä tuotetestaus. Jotkut henkilöt voivat vastustaa uudelleen käytettävien materiaalien ohjelmaa, mutta anna heidän kuitenkin testata tuotteita.

6. Laadi selkeä prosessi todellisen muutoksen suorittamiseen (sellainen, jossa vanhat kertakäyttöiset tuotteet käytetään loppuun jne.).

7. Jatka tuen ja koulutuksen tarjoamista henkilöstölle, ja mittaa ja arvioi tuloksia. 


\title{
Kokonaiskäyttökustannusten käyttö
}

\author{
Kokonaiskäyttökustannukset (TCO) kertovat tuotteeseen liittyvät kustannukset \\ koko tuotteen käyttöiän ajan hankinnasta käytön loppuun asti. Kun päätökset \\ tehdään kokonaiskäyttökustannuksiin eikä hankintahintaan perustuen, voidaan \\ edistää ympäristön huomioimista.
}

\begin{abstract}
Valittaessa eri tekstiilituotteiden väliltä halvin tuote ei usein ole kaikkein ympäristöystävällisin. Kun tuotteen elinkaarikustannukset on laskettu, ympäristön hyötyjen ja budjettien hallinnan välillä voi kuitenkin olla parempi yhteensopivuus. Näin voi olla erityisesti kestävämmissä materiaaleissa, jotka säästävät sekä rahaa että ympäristöresursseja, vaikka ne maksaisivatkin aluksi enemmän. Valinta kerta- ja kestokäyttöisten tekstiilien välillä (ks. luku 6, sivut 28-29) voi myös selkeytyä elinkaarikustannusten tai kokonaiskäyttökustannuksien (TCO) laskemisen jälkeen.
\end{abstract}

Kokonaiskäyttökustannukset (TCO) kertovat tuotteeseen liittyvät kustannukset koko sen käyttöiän ajan hankinnasta käytön loppuun asti. TCO tarjoaa kehyksen ja kielen, jolla kuvataan ja mitataan kestävien valintojen vaikutuksia tavalla, jota hankintapäälliköt ymmärtävät. TCO-lukuja voidaan käyttää esim. yhdessä elinkaarianalyysin (LCA) ja samanlaisten lähestymistapojen kanssa, jotta voidaan selvittää mahdollisuuksia sekä kustannussäästöihin että kestävyyshyötyihin $\mathrm{mm}$. energia- ja vesitehokkuuden suhteen.

TCO:n käyttö vaatii tietämystä tekijöistä, jotka täytyy sisällyttää laskelmiin, sekä hyvää yleiskuvaa tuotteiden käytöstä. Terveydenhoidon tekstiilituotteiden osalta tämä sisältää tiedot seuraavista:
- alkuperäinen hinta

- käyttökerrat ennen kuin tuote on kulunut loppuun

- pesuun käytetty energia, vesi ja muut kulut

- korjaustarve ja kustannukset

- hävityskustannukset.

Voit käyttää TCO-kustannuksia valitessasi eri tekstiilien toimittajien välillä (ks. Rawiczin sairaalan tapaus sivulla 28). Muista pyytää toimittajia dokumentoimaan tekstiiliensä kestävyys (käyttökerrat ennen kuin tuote rikkoutuu), koska tämä on tärkeä kokonaiskustannuksissa huomioitava tekijä. Jos mahdollista, liitä mukaan sopimuslauseke, jonka mukaan heidän on pysyttävä tällä tasolla.

Suurimmat tekstiilipalveluyritykset ovat kehittäneet TCO-lukuja, joiden avulla he voivat minimoida kustannuksensa, ja saattavat tarjota näitä laskelmia sinullekin. Sama koskee kansallisia hankkijoita, kuten Sykehusinnkjøp HF:ää Norjassa. Paikallisen, kunnallisen tai sairaalatason hankintayksiköt voivat kuitenkin pitää TCO-laskureiden laatimista kaikille hankkimilleen tuotteille, myös tekstiileille, liikaa resursseja vievänä.

Vaikka käytössäsi on useita työkaluja ja vinkkejä TCO:n käytöstä, saatavilla ei kuitenkaan vielä ole julkisia TCO-laskureita terveydenhuollon tekstiilituotteille. Löydät lisää tarkempia tietoja ja työkaluja näistä linkeistä: 


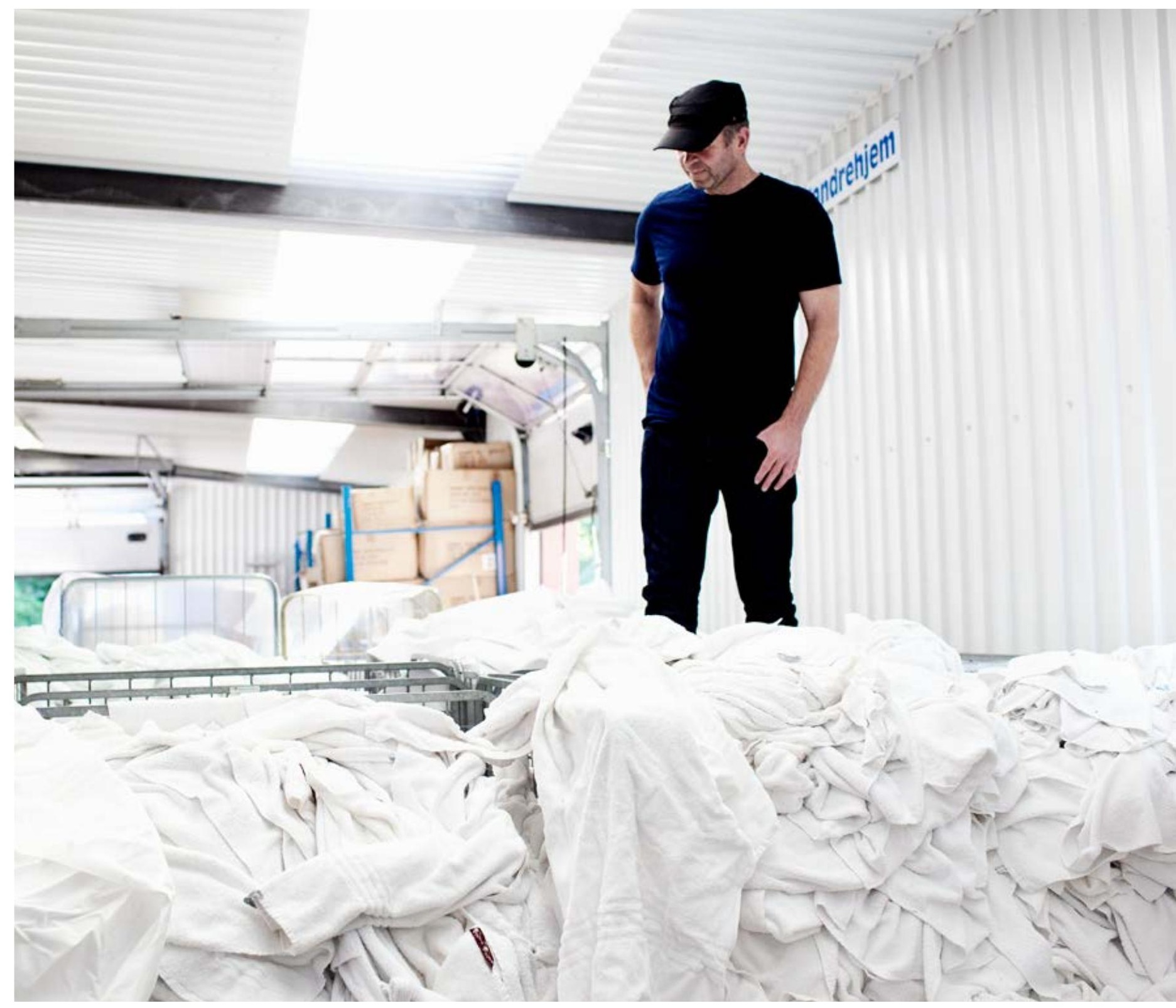

\section{- Tanskalainen foorumi kestäville hankinnoille}

- kansallinen verkosto tiedonjakofoorumilla, jossa hankintayksiköt julkisista ja yksityisistä organisaatioista voivat kertoa parhaista käytänteistään, metodeistaan ja työkaluistaan hankinnoissa, mukaan lukien TCO-työkalut (tanskankielinen linkki)
- Vastuullinen hankintayksikkö- verkkosivu, josta hankintayksiköt löytävät ympäristöä säästävät kriteerit, jotka voidaan kopioida ja liittää tarjousasiakirjoihin monille eri tuotealueille. Lisäksi saatavilla on kokonaiskustannusten työkaluja valituille tuotealueille (tanskankielinen linkki)

- BSR (Business Social Responsibility) (englanninkielinen linkki) 
Luku 8

\section{Tietoja oppaasta ja sen taustaverkostostosta}

Tämä opas on kehitetty osaksi Pohjoismaista kestävän muodin ja tekstiilien toimintasuunnitelmaa, "Well-dressed in Clean Environment", ja se on Pohjoismaiden

ministerineuvoston rahoittama.

Pohjoismainen toimintasuunnitelma pitää ympäristöä säästäviä julkisia hankintoja tärkeänä vipuvaikutuksena. Ensinnäkin siksi, että julkinen sektori itsessään on tekstiilien merkittävä kuluttaja - se käyttää niitä 10 miljardin arvosta vuosittain EU-tasolla ${ }^{13}$. Toiseksi ympäristöä säästävät julkiset hankinnat voivat muodostaa markkinoita ja prosesseja, joilla voi olla positiivisia seurauksia ja ne inspiroivat myös yksityisiä hankkijoita.

Opas on laadittu yhteistyössä Pohjoismaisen terveydenhuoltosektorin hankkijaverkoston kanssa. Verkoston on perustanut Tanskan ympäristönsuojelulaitos Pohjoismaiden ministerineuvoston puolesta. PlanMiljø ApS ja TEM ovat auttaneet prosessissa, edistäneet verkostoa ja tehneet luonnoksen oppaasta. Verkosto koostuu seuraavista henkilöistä:

Christian Leth Christensen, Keski-Tanskan alve Anette Bjørn, Etelä-Tanskan alve Susanne G. Sørensen, Pohjois-Jyllannin alve, Tanska Anya S. Midjord ja Gudna á Rógvi Joensen, LSH:n sairaala, Färsaaret Isa-Maria Bergman, Motiva, Suomi Outi Kalske, Varsinais-Suomen sairaanhoitopiiri
Karólína Guðmundsdóttir, Landspítali Háskólasjúkrahús, Islanti Trude Ertresvåg, Sykehuspartner HF, Norja Kine Stjern ja Evy Pleym, Sykehusinnkjøp HF, Norja Anna Chistiansson, Uphandlingsmyntigheten, Ruotsi Anja Ekstrand ja Sofie Areborn, Skånen alve, Ruotsi Jonna Bjuhr Männer, Koncernkontoret Region Västra Götaland, Ruotsi

Christina Nukala-Pengel, Ålands Hälso- och Sjukvård, Ahvenanmaa

Rikke Dreyer ja Lena Stenseng, Ecolabel Tanska

Weronika Rehnby, TEKO

Malin Hill, Berendsen $A B$

Hanne Selsholt Britz ja Søren Vinzent, De Forenede Dampvaskerier A/S

Fredrik Johansen, FOV Fabrics $A B$

Kate Riley, Oakdene Hollins

Rikke Fisher-Bogason ja David Watson, PlanMiljø Marie Pettersson ja Daniel Eriksson, TEM

Birgitte Jørgensen Kjær ja Anne-Mette Lysemose Bendsen, Tanskalainen EPA

Kysymyksiä oppaasta ja verkostosta voidaan lähettää Birgitte Jørgensen Kjærille Tanskan ympäristöhallitukseen: bjk@mst.dk

\footnotetext{
${ }^{13} \mathrm{http} / / /$ susproc.jrc.ec.europa.eu/textiles/docs/141222\%20EU\%20GPP\%2OTextiles_Technical\%2Obackground\%2Oreport_Draft\%20 version\%201.pdf
} 
Pohjoismaiden ministerineuvosto

Ved Stranden 18

DK-1061 København K

www.norden.org

Tämä opas on tarkoitettu pohjoismaisille terveydenhuoltosektorin hankkijoille, jotka ovat vastuussa tekstiilituotteiden ja -palveluiden hankinnasta. Opas auttaa heitä kehittämään prosesseja sopivien ja käytännöllisten ympäristökriteerien laatimiseksi hankinta-asiakirjoihin. Hankintayksiköt saavat tietää, millä tekijöillä tuotannossa ja tekstiilien huollossa on eniten merkitystä ympäristölle ja miten niitä voidaan käsitellä kriteerien avulla. He tutustuvat ympäristömerkkien rooliin hankinnoissa ja löytävät linkkejä valmiisiin kriteereihin ja muita hyödyllisiä tietoja kansallisista hankintalaitoksista. Opas on laadittu yhteistyössä pohjoismaisen terveydenhuoltosektorin hankkijoiden kanssa osana pohjoismaisen kestävän muodin ja tekstiilien toimintasuunnitelmaa "Well-dressed in Clean Environment". Se on Pohjoismaiden ministerineuvoston rahoittama. 